Бондарєва Т. Г., к.е.н., доцент (Національний університет водного господарства та природокористування, М. Рівне), Немкович О. Б., к.е.н. (Відокремлений структурний підрозділ «Рівненський коледж Національного університету біоресурсів і природокористування України» м. Рівне, Україна)

\title{
ПРЯМІ ІНВЕСТИЦІЇ ЗА КОРДОН: СТАН ТА ПЕРСПЕКТИВИ РОЗВИТКУ
}

У статті розглянуто суть прямих інвестицій у системі понять, які визначають особливості інвестування за кордон. Проведено аналіз прямих інвестицій з України в економіки інших країн світу. Визначено переваги та недоліки закордонного інвестування та виявлено складності його здійснення. Зосереджено увагу на новій системі валютного регулювання, яка забезпечить лібералізацію умов інвестування за кордон для юридичних та фізичних осіб.

Ключові слова:інвестиції, інвестиції за кордон, прямі іноземні інвестиції; валютне регулювання.

Постановка проблеми. Участь різних країн світу у процесах глобалізації та інтеграції світових ринків обумовлює підвищення ролі міжнародного інвестування як одного із факторів економічного зростання. Сьогодні у світі спостерігається активне збільшення міжнародних інвестиційних потоків. Щодо України, то після помітного спаду обсягів залучених прямих інвестицій (акціонерного капіталу) в економіку України у 2014-2015 рр., пов'язаного з різким ускладненням політичної ситуації, спостерігається їх поступове зростання. Так у 2017 р. вони склали 39144,0 млн дол. США, що на 2989,6 млн дол. США або 8,3\% більше, ніж у 2015 р. Інвестиційна політика нашої держави спрямована на лібералізацію та заохочення інвестицій. Водночас Україна не тільки залучає інвестиції, але і вкладає кошти в економіки інших країн світу. Значне місце у цьому процесі займає пряме інвестування з України за кордон. Дане питання $є$ одним із пріоритетних напрямів економічних досліджень.

Аналіз останніх досліджень і публікацій. В українській економічній науці дослідженням проблем сутності та особливостей структури міжнародних інвестицій та їх впливу на економічне зростання української економіки присвячені роботи багатьох вітчизняних вчених-економістів, таких як В. Геєць, Г.Е. Гронтковська, К.Г. Касянюк, Д. Лук'яненко, А. Мерзляк, І.П. Мойсеєнко, Л.П. Овчарова, Л.О. Петко- 
ва, О.І. Рогач, А.С. Філіпенко, А.В. Пехник та інші. Однак сьогодні залишається мало дослідженим питання щодо основних тенденцій інвестування саме з України в економіки різних країн світу.

Формулювання цілей статті. Проаналізувати сучасний стан здійснення прямих інвестицій за кордон та визначити перспективи його розвитку з урахуванням змін валютного законодавства.

Виклад основного матеріалу дослідження. Згідно Закону України «Про інвестиційну діяльність» від 18.09.1991 р. № 1560-XII, інвестиціями є всі види майнових та інтелектуальних цінностей, що вкладаються в об'єкти підприємницької та інших видів діяльності, в результаті якої створюється прибуток (доход) та/або досягається соціальний та екологічний ефект [1]. Якщо реалізація інвестицій здійснюються суб'єктами, які належать до різних держав, тобто $є$ резидентами та нерезидентами стосовно даної країни, то такі інвестиції $€$ міжнародними. Залежно від напрямів руху капіталів міжнародні інвестиції поділяються на іноземні інвестиції та інвестиції за кордон. Стосовно України - це інвестиції із-за кордону в економіку України та інвестиції з України в економіки країн світу. Іншими словами, іноземні інвестиції здійснюються іноземними суб'єктами господарської діяльності в Україні [2]. Інвестиції ж за кордон передбачають вкладення вітчизняними суб'єктами інвестицій валютних цінностей за межами України (рис. 1).

Як зазначено на рис. 1, фінансові інвестиції за кордон поділяються на прямі та портфельні. Прямі інвестиції - це категорія міжнародної інвестиційної діяльності, яка відображає прагнення інституційної одиниці - резидента однієї країни (прямого інвестора) здійснювати істотний вплив або контроль на діяльність підприємства, що $€$ резидентом іншої країни (підприємство прямого інвестування) [3]. Згідно нині діючої «Інструкції про порядок видачі індивідуальних ліцензій на здійснення інвестицій за кордон» прямі інвестиції - це валютна операція, яка передбачає внесення коштів до статутного фонду юридичної особи в обмін на корпоративні права, емітовані такою юридичною особою [4].

Основною характерною ознакою віднесення інвестиції до прямих, яка відрізняє їх від портфельних інвестицій, $€$ контроль над об'єктами інвестування. У різних країнах встановлюються різні кількісні параметри частки іноземної участі в акціонерному капіталі компанії. Так за міжнародними нормами вона складає 25\%, за канадськими - 50\%; за американськими - 10\%. За українськими нормами, якщо капітал/права власності прямого інвестора складає від 10\% до $50 \%$ вартості статутного капіталу або голосів в управлінні підприємства прямого інвестування, то інвестор здійснює істотний вплив на 


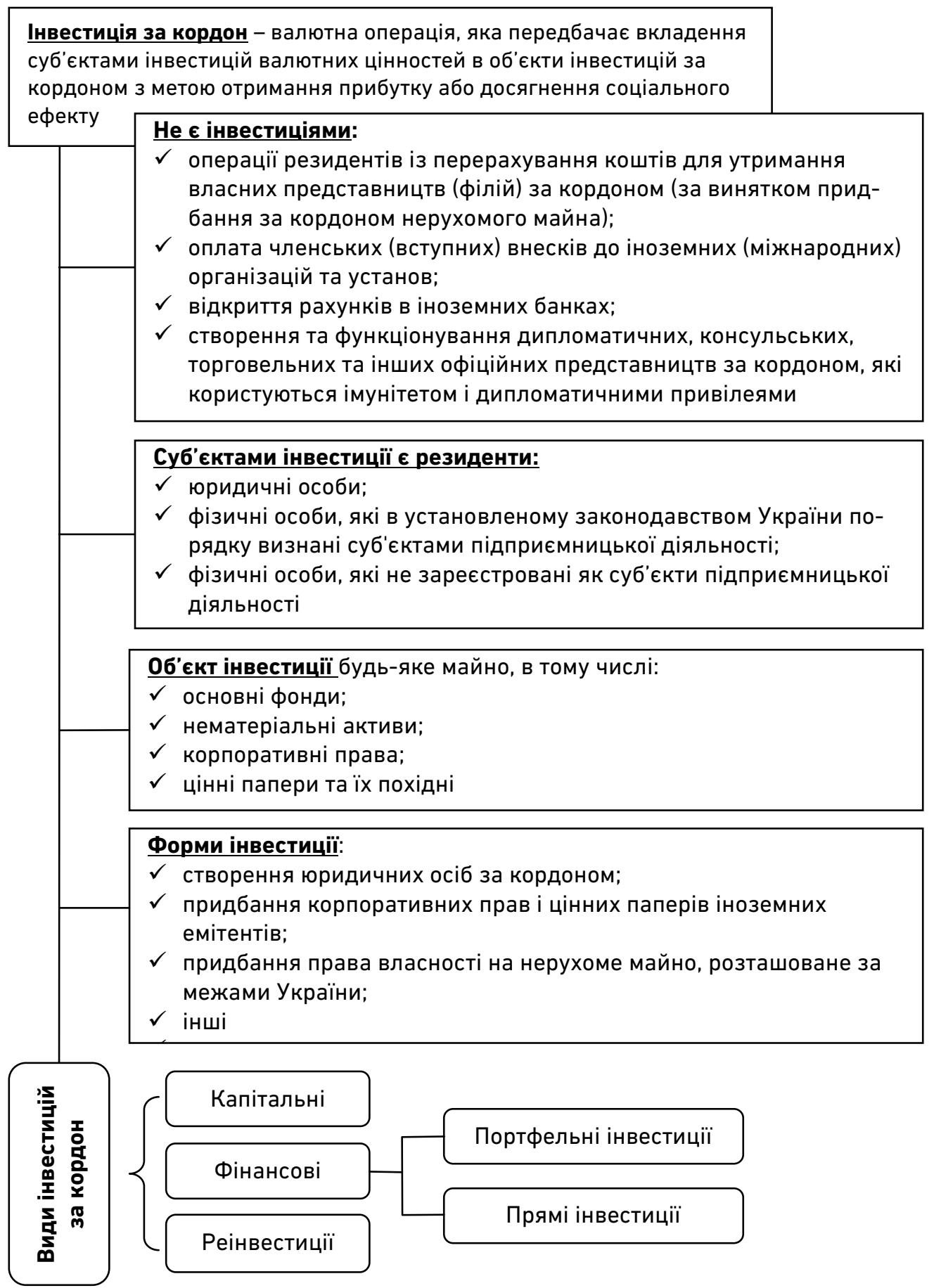

Рис. 1. Суб'єкти, об'єкти та класифікація інвестицій за кордон Джерело: побудовано авторами за даними [4] 
діяльність такого підприємства. Якщо ж капітал/права власності прямого інвестора складає не менше $50 \%$ вартості статутного капіталу або голосів в управлінні підприємства прямого інвестування, у такому разі інвестор здійснює контроль за діяльністю такого підприємства [4].

Крім того, до прямих інвестицій також відносять інвестиції, що отримані на основі концесійних договорів і договорів про спільну інвестиційну діяльність, а також кредитні ресурси, що надані або отримані в рамках операцій між підприємством прямого інвестування та прямим інвестором [4].

Проведемо аналіз стану, динаміки, географічної, галузевої та регіональної структури прямих інвестицій (акціонерного капіталу), які здійснюють українські інвестори, що мають не менше $10 \%$ у загальному обсязі статутного капіталу підприємства-нерезидента або не менше $10 \%$ голосів у його управлінні (у кожному окремому підприємстві-нерезиденті, а не у підсумку) (рис. 2-5).

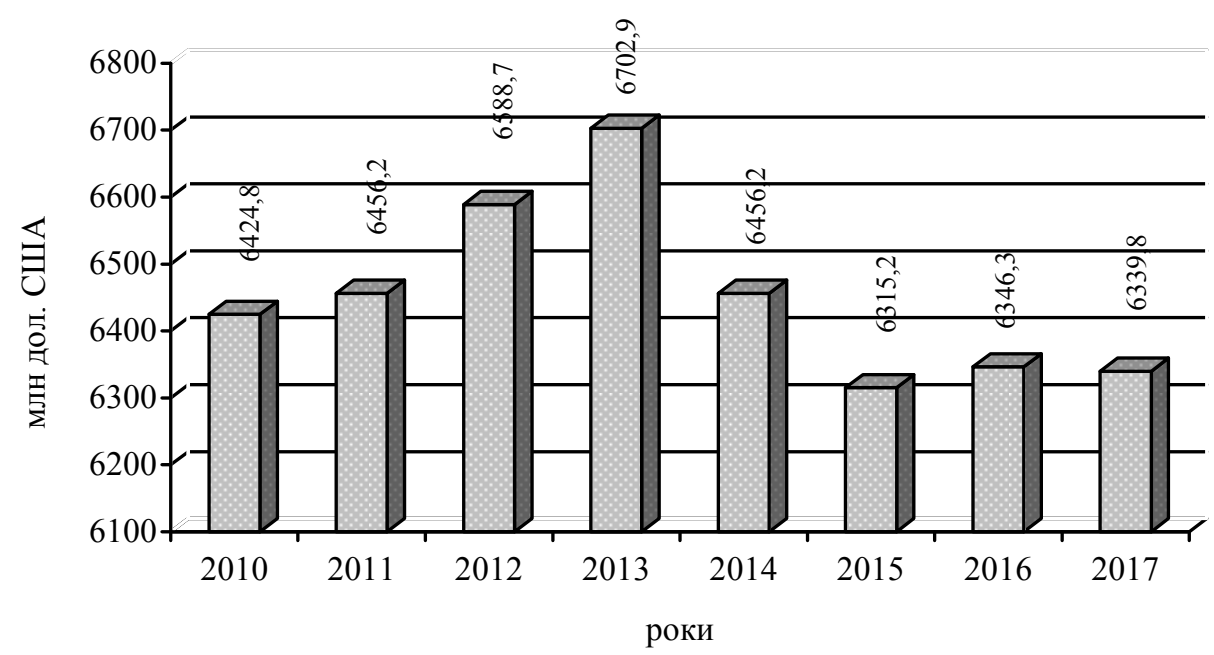

Рис. 2. Динаміка прямих інвестицій (акціонерного капіталу) з України в економіці країн світу у 2010-2017 рр.

Джерело: побудовано авторами за даними [5]

Як свідчать дані рис. 2, впродовж 2010-2017 рр. обсяг здійснених з початку інвестування прямих інвестицій (акціонерного капіталу) з України в економіці країн світу коливався в межах 6,3-6,7 млрд дол. США, досягнувши свого максимуму у 2013 р., і знизившись до мінімуму у 2015 р. У наступних періодах спостерігалося незначне коливання темпів приросту досліджуваного показника, яке не перевищувало $0,5 \%$. 
На кінець 2017 р. обсяг прямих інвестицій з України за кордон склав 6,3 млрд дол. США. 3 них, як і у попередніх періодах, основна частина (5,9 млрд дол. США або 93,6\% загального обсягу прямих інвестицій в країни світу) була спрямована до Кіпру. Традиційно серед країн-реципієнтів залишаються Російська Федерація (2,4\%), Латвія $(1,2 \%)$ та Віргінські острови (Британія) (1,0\%). Загальна питома вага прямих інвестицій, спрямованих в Угорщину, Швейцарію, Нідерланди, Австрію та інші країни не перевищувала 1,9\%.

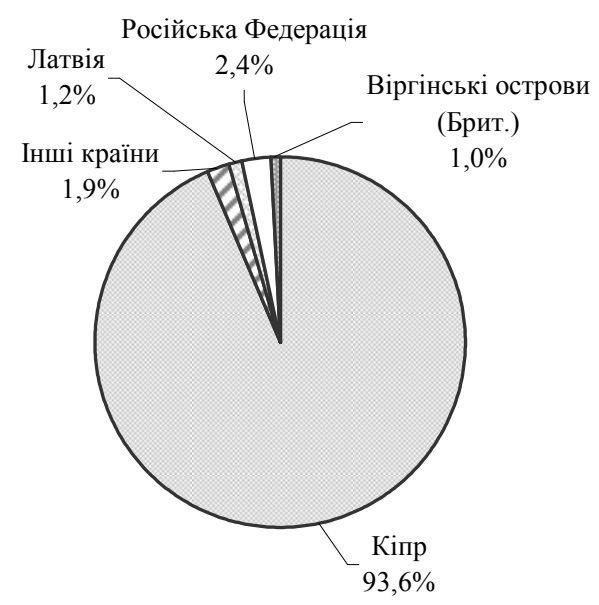

Рис. 3. Структура прямих інвестицій (акціонерного капіталу) з України в економіці країн світу у 2017 p.

Джерело: побудовано авторами за даними [5]

Порівнюючи обсяги прямих інвестицій з України за кордон у піковому 2013 р. з показниками 2017 р., відслідковується така динаміка: найбільший приріст відбувся на Віргінських островах (Британія) (136,4\%) та у Швейцарії (68,3\%); найбільше скорочення спостерігається у Російській федерації (60,0\%); на Кіпрі та в Угорщині показники практично не змінилися.

Провідними сферами економічної діяльності за обсягами інвестицій у 2017 р., як і раніше, залишаються професійна, наукова і технічна діяльність (5978,8 млн дол. США або 94,3\%), промисловість (123,8 млн дол. США або 2,0\%), фінансова та страхова діяльність (79,1 млн дол. США або 1,2\%). Загальна частка прямих інвестицій за кордон, вкладених в усі інші види економічної діяльності складає $2,5 \%$. 


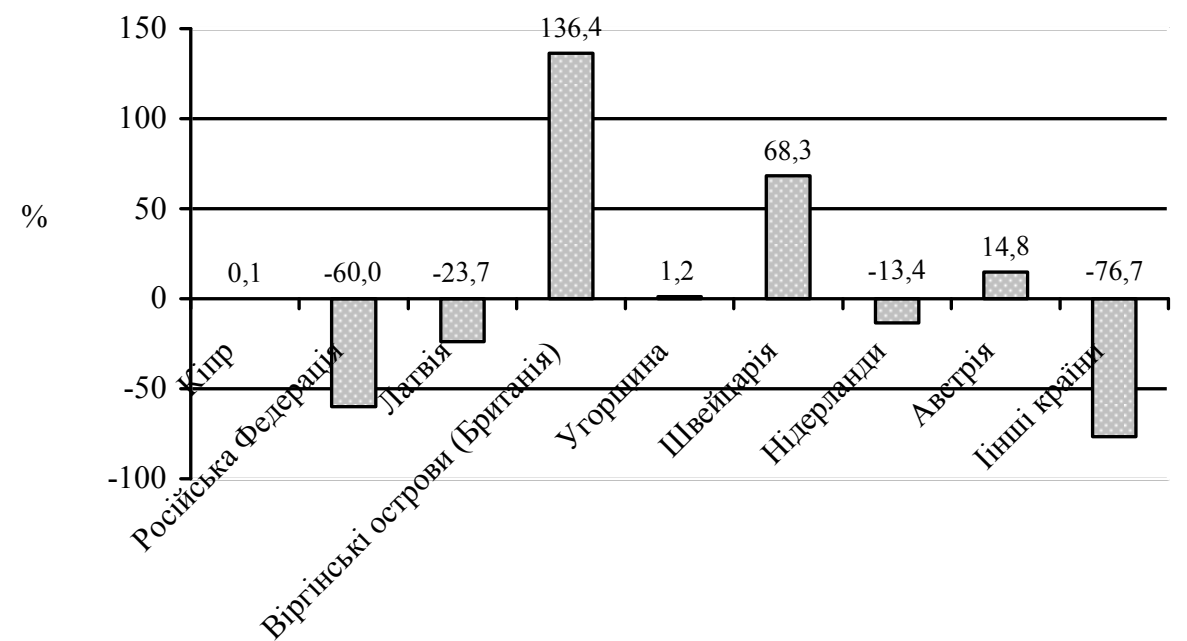

Рис. 4. Темп приросту обсягів прямих інвестицій (акціонерного капіталу) 3 України в економіці країн світу у 2017 р. порівняно з 2013 р.

Джерело: побудовано авторами за даними [5]

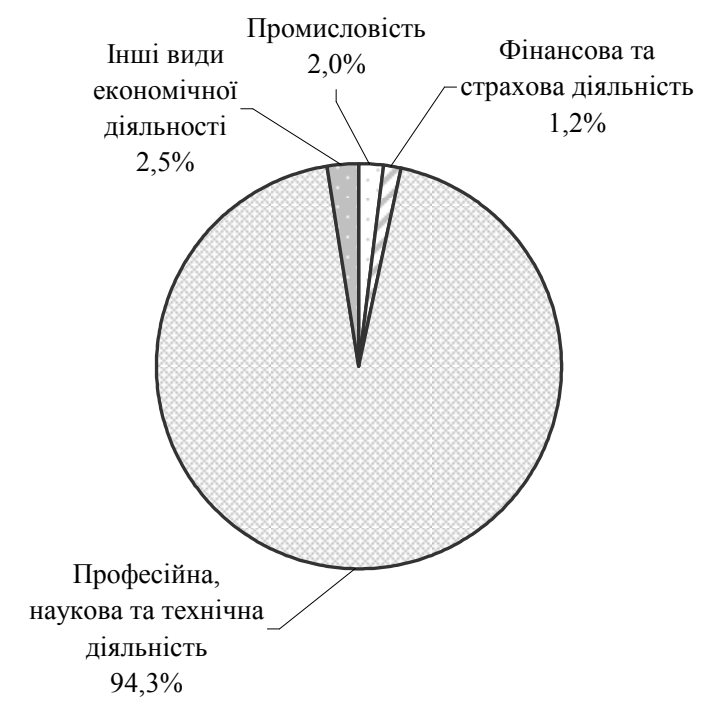

Рис. 5. Структура прямих інвестицій (акціонерного капіталу) з України за видами економічної діяльності у 2017 р.

Джерело: побудовано авторами за даними [5]

У 2010-2017 рр. практично всі прямі інвестиції за кордон спрямовувалися із Донецької обл. На 31.12.2017 р. їх обсяг з початку інвестування склав 5943,7 млн дол. США, що становило 93,8\% загального обсягу прямих інвестицій за межі держави. 4,4\% інвестицій, що в грошовому еквіваленті складає 278,7 млн дол. США, були спрямо- 
вані з Києва та Київської обл. Частка інших регіонів України становила 1,9\% або 117,4 млн дол. США.

Отже, узагальнюючи вищевикладене, можна стверджувати, що переважна частина прямих інвестицій з України здійснюється на Кіпр з Донецької обл. При цьому практично увесь український капітал спрямовується у невиробничі галузі економіки за кордоном, що свідчить про відсутність мети нарощення виробничих потужностей чи освоєнням нових ринків збуту. Зауважимо, що найбільші обсяги прямих інвестицій в Україну здійснюються також з Кіпру. Станом на 31.12.2017 р. вони складали 10,0 млрд дол. США або 25,6\% загального обсягу прямих інвестицій в Україну. Все це наштовхує на думку, що через прямі інвестиції за кордон може здійснюватися легальний непродуктивний відплив капіталу.

Як відомо, Кіпр є популярною територією для формування схем оптимізації оподаткування та виведення капіталів. Це негативно позначається на стійкості фінансової системи України. Капітали, які виводяться у інші економічні території, а потім повертаються у вигляді портфельних інвестицій або позик у національну економіку, можуть легко вилучатись з неї, що є особливо небезпечним у періоди кризових явищ. Виведення прибутків за межі національної економіки призводить до перерозподілу податкового навантаження з бізнесу на населення України [6, С. 69]. На жаль, Україні відомі не так багато прикладів, коли вітчизняні компанії ставали власниками активів за кордоном, а не просто здійснювали легалізацію чи вивід коштів.

Таким чином, аналіз офіційних статистичних даних свідчить, що у процесі дослідження прямих інвестицій з України за кордон варто звертати увагу на використання офшорних зон у формуванні інвестиційних потоків. Водночас багато каналів відтоку вітчизняного капіталу $є$ нелегальними і залишаються неврахованими, а отже дана проблема потребує вирішення. Зазначимо, що у міжнародній практиці загальновідомим є метод «дзеркальної статистики», який дозволяє оцінити обсяги неврахованого відтоку капіталу шляхом формування Міжнародним Валютним Фондом інформації про обсяги прямих іноземних інвестицій у порівнянні з даними про вхідні та вихідні інвестиційні потоки, що представлені у звітності країнпартнерів. При виявленні значного прихованого відпливу фінансових ресурсів з країни за кордон, необхідно посилювати захист національної фінансової системи через застосування податкових та інших важелів.

Прямі інвестиції за кордон є одним із способів виходу українського інвестора на міжнародний ринок поряд із експортом та спіль- 
ною підприємницькою діяльністю. Він потребує наявності у інвестора значних конкурентних переваг, а саме: можливість економії за рахунок масштабу; вагомі науково-технічні досягнення; наявність досвіду діяльності на міжнародному ринку; застосування ефективних управлінських концепцій; наявність стратегії на зовнішньому ринку; високий рівень забезпеченості ресурсами; вільний доступ до великого капіталу; ефективне управління ризиками зовнішньоекономічної діяльності; висока якість продукції, відповідність ії певним технічним умовам або споживчим стандартам та ін.

На жаль, сьогодні українські компанії-інвестори володіють обмеженою кількістю переваг. Реально розширити свій вплив і вийти на ринки зарубіжних країн можуть лише представники великого бізнесу, які впевнені у якості власного продукту. Для них пряме іноземне інвестування за кордон $є$ досить ефективним способом експансії на міжнародний ринок, водночас воно пов'язане із значними труднощами, а саме:

- психологічними (мовні бар'єри, незнання культури, особливостей поведінки та основних цінностей населення інших країн тощо);

- юридичними (недостатня обізнаність у закордонному законодавстві щодо якості товарів, обмежень ввезення товарів, захисту навколишнього середовища тощо);

- інформаційними (недостатнє інформаційне забезпечення);

- ризиками національних ринків (політична нестабільність, різкі коливання курсів валют, акцій, зміни відсоткових ставок, регіональні та світові кризи і т. д.);

- додатковими трансакційними витратами та ін.

Важливим $є$ питання, що саме спонукає бізнесменів інвестувати за кордон? Основними мотивами для них є:

- отримання більшого прибутку за кордоном;

- прагнення домінувати на ринку, можливість його монополізації;

- подолання митних бар'єрів, які заважають ввезенню товарів в країну-імпортера;

- прагнення до географічної диверсифікації виробництва;

- збереження експортного потенціалу;

- зростання ефективності виробництва через прямий доступ до національних ринків ресурсів;

- поширення новітніх технологій та домінування окремих країн у розвитку цих технологій;

- більш низькі екологічні стандарти;

- стабільніший політичний стан, економічне зростання і при- 
вабливіший інвестиційний клімат в країні-реципієнті капіталу тощо.

Разом з тим, переважна більшість вітчизняних інвесторів наразі з недовірою відносяться до міжнародних інвестицій. Найбільш активно власниками активів за кордоном стають компанії харчової, аграрної та гірничо-металургійної промисловостей. Серед них варто виділити фабрики компанії «Миронівський хлібопродукт» у Нідерландах, Словаччині; завод «Т.В. Fruit»; фабрики «Рошен» в ЄС; потужності групи «Метінвест» в Італії (Trametal), Болгарії (Promet Steel), США (United Coal Company), Великобританії (Spartan UK). Вихід на міжнародну арену для них продиктований, перш за все, такими вигодами, як використання капіталу з більш високою віддачею, збереження ринків збуту та більш сприятливі економічні умови функціонування.

Водночас інвестування за кордон може бути вигідним не тільки для бізнесу, але і для економічного розвитку України загалом, оскільки відкриває досить широкі перспективи і надає можливості для: участі України у формуванні міжнародної економічної структури; зростання міжнародної репутації; розвитку інновацій та технологій; впровадження в практику передового економічного досвіду розвинених країн та ін.

Проте можуть мати місце і негативні наслідки, такі як: скорочення обсягів національного внутрішнього продукту внаслідок відтоку капіталу за кордон; погіршення платіжного балансу країни у разі виникнення негативного сальдо за статтею «інвестиції», якщо відтік інвестицій за кордон стане більшим за притік та ін.

Інвестиційна діяльність суб'єктів України за їі межами регулюється законодавством іноземної держави, на території якої ця діяльність здійснюється, відповідними договорами України, а також спеціальним законодавством України [1].

Світовий досвід показує, що держава повинна відігравати важливу роль у забезпеченні достатнього інвестиційного потенціалу країни. Сьогодні в Україні діє режим обмеження інвестування за межі держави, утім завдяки довгоочікуваній лібералізації валютного законодавства активність міжнародної інвестиційної позиції України на світовій арені може покращитися. Йдеться, перш за все, про уведення в дію з 07.02.2019 р. Закону України «Про валюту та валютні операції», яким будуть скасовані необхідність отримання індивідуальних ліцензій НБУ та можливість вільно інвестувати кошти за кордон у рамках визначеної суми. Таким чином, потенційні інвестори при сприятливому макроекономічному кліматі будуть мати змогу, спираючись на нові стандарти правового регулювання, реалізувати інвестиційні проекти за кордоном, що є надзвичайно важливим для 
нашої країни з позиції економічного зростання у довгостроковій перспективі.

Звичайно абсолютна лібералізація не відбудеться, оскільки банки продовжуватимуть здійснювати контроль за операціями клієнтів, проте певні позитивні зрушення щодо активізації міжнародного інвестування безперечно повинні відбутися.

Висновки. Інвестиції виконують важливу функцію прискорення та оптимізації руху капіталу та можуть бути імпульсом для економічного зростання. Україна не $є$ вагомим гравцем на міжнародному ринку капіталів. На даний час обсяг прямих інвестицій з України в економіки країн світу $€$ незначним. Лібералізація валютного законодавства повинна активізувати інвесторів з України розміщувати свої активи за межами держави. Вихід вітчизняних інвесторів на ринки інших країн та здійснення інвестицій за кордон сприятиме поліпшенню позицій України в процесі їі інтеграції у світову економіку.

1. Про інвестиційну діяльність : Закон України від 18.09.1991 р. № 1560-XII. URL: https://zakon.rada.gov.ua/laws/show/1560-12. (дата звернення: 15.05.2019). 2. Про зовнішньоекономічну діяльність : Закон України від 16.04.1991 p. № 959-XII. URL: https://zakon.rada.gov.ua/laws/card/959-12. (дата звернення: 15.05.2019). 3. Методологічні положення 3 організації державного статистичного спостереження щодо інвестицій зовнішньоекономічної діяльності : наказ Державної служби статистики України від 03.10.2014 p. № 284 із змінами, затвердженими наказом Держстату від 28.03.2017 p.

№ 70.

URL: http://www.ukrstat.gov.ua/metod_polog/menu/menu_/2_zed.htm. (дата звернення: 15.05.2019). 4. Інструкція про порядок видачі індивідуальних ліцензій на здійснення інвестицій за кордон : Постанова Правління Національного банку України від 16 березня 1999 року № 122. URL: https://zakon.rada.gov.ua/laws/show/z0259-99. (дата звернення: 15.05.2019). 5. Державна служба статистики України / ред. І. Є. Вернера. Україна у цифрах 2017 рік : статистичний збірник. К., 2018. 240 с. 6. Якубовський С. О., Родіонова Т. А. Світовий досвід контролю за рухом іноземного капіталу та шляхи його використання в Україні. Актуальні проблеми міжнародних відносин. 2014. Вип. 121(2). С. 65-73. URL: http://nbuv.gov.ua/UJRN/apmv_2014_121\%282\%29_10. (дата звернення: 15.05.2019).

\section{REFERENCES:}

1. Pro investytsiinu diialnist : Zakon Ukrainy vid 18.09.1991 r. № 1560-XII. URL: https://zakon.rada.gov.ua/laws/show/1560-12. (data zvernennia: 15.05.2019). 2. Pro zovnishnoekonomichnu diialnist : Zakon Ukrainy vid 16.04.1991 r. № 959-XII. URL: https://zakon.rada.gov.ua/laws/card/959-12. 
(data zvernennia: 15.05.2019). 3. Metodolohichni polozhennia z orhanizatsii derzhavnoho statystychnoho sposterezhennia shchodo investytsii zovnishnoekonomichnoi diialnosti : nakaz Derzhavnoi sluzhby statystyky Ukrainy vid 03.10.2014 r. № 284 iz zminamy, zatverdzhenymy nakazom $\begin{array}{llllll}\text { Derzhstatu vid } & \text { 28.03.2017 } & \text { r. } & \text { № } & 70 . & \text { URL: }\end{array}$ http://www.ukrstat.gov.ua/metod_polog/menu/menu_/2_zed.htm.

4. Instruktsiia pro poriadok vydachi indyvidualnykh litsenzii na zdiisnennia investytsii za kordon : Postanova Pravlinnia Natsionalnoho banku Ukrainy vid 16 bereznia 1999 roku № $122 . \quad$ URL: https://zakon.rada.gov.ua/laws/show/z0259-99. (data zvernennia: 15.05.2019). 5. Derzhavna sluzhba statystyky Ukrainy / red. I. Ye. Vernera. Ukraina u tsyfrakh 2017 rik : statystychnyi zbirnyk. K., 2018. 240 s. 6. Yakubovskyi S. 0., Rodionova T. A. Svitovyi dosvid kontroliu za rukhom inozemnoho kapitalu ta shliakhy yoho vykorystannia v Ukraini. Aktualni problemy mizhnarodnykh vidnosyn. 2014. Vyp. 121(2). S. 65-73. URL: http://nbuv.gov.ua/UJRN/apmv_2014_121\%282\%29_10. (data zvernennia: 15.05.2019).

Рецензент: д.е.н., доцент Осадча О. О. (НУВГП)

Bondarieva T. H., Candidate of Economics (Ph.D.), Associate Professor (National University of Water and Environmental Engineering, Rivne), Nemkovych O. B., Candidate of Economics (Ph.D.) (Rivne College of National University of Life and Environmental Sciences of Ukraine, Rivne)

\section{DIRECT INVESTMENTS ABROAD: CONDITION AND DEVELOPMENT PROSPECTS}

The essence of concepts of the «investment», «international investment», «investment abroad» are reviewed in this article. The subjects and objects of foreign investment are defined. The types of investments abroad are submitted. The attention is focused on the direct investment. It is emphasized that the investment is direct if the capital / property rights of a non-resident make not less than ten percent of the authorized capital value of the resident enterprise or non-resident has at least ten percent of the votes in the management of the resident enterprise. It is noted that the direct investments include investments received on the basis of concession agreements and agreements on the joint investment activity; credit resources provided / received within the transactions between the direct investment enterprise and the direct investor. 
The structure and dynamics analysis of the direct investments from Ukraine to the European Union countries and other countries is carried out. The patchy trends in the volumes dynamics of such investments during the last years have been revealed. It was determined that most of the investments were made in professional, scientific and technical activities. It is revealed that Ukraine mainly invests in Cyprus.

The advantages and disadvantages of foreign investment are determined and the difficulties of its implementation are revealed. The attention is focused on the new system of currency regulation, which will ensure the liberalization of conditions for investing abroad for legal entities and individuals.

Keywords: investments, investments abroad, direct investments; currency regulation.

Бондарева Т. Г., к.э.н., доцент (Национальный университет водного хозяйства и природопользования, г. Ровно), Немкович О. Б., к.э.н. (Обособленное структурное подразделение «Ровенский колледж Национального университета биоресурсов и природопользования Украины»г. Ровно)

ПРЯМЫЕ ИНВЕСТИЦИИ ЗА ГРАНИЦУ: СОСТОЯНИЕ И ПЕРСПЕКТИВЫ РАЗВИТИЯ

В статье рассмотрено сущность прямых инвестиций в системе понятий, которые определяют особенности инвестирования за границу. Проведен анализ прямых инвестиций из Украины в экономики других стран мира. Определены преимущества и недостатки зарубежного инвестирования и выявлены сложности его осуществления. Сосредоточено внимание на новой системе валютного регулирования, которая обеспечит либерализацию условий инвестирования за границу для юридических и физических лиц.

Ключевые слова: инвестиции, инвестиции за границу, прямые иностранные инвестиции; валютное регулирование. 